\title{
Microbiological Assessment of Housekeeping Practices and Environmental Impact of Selected Abattoirs in Lagos and Ogun States of Nigeria
}

\author{
1,2 F. Ayoade, and ${ }^{1}$ E.O. Olayioye \\ Department of Biological Sciences, College of Natural Sciences, Redeemer's University PMB 230, Ede, Osun State, \\ Nigeria \\ Correspondence to: Dr. Femi Ayoade. E-mail : ayoadef@run.edu.ng
}

Original submitted in on 24th November 2015. Published online at www.m.elewa.org on $31^{\text {st }}$ March 2016 http://dx.doi.org/10.4314/jab.v99i1.2

\begin{abstract}
Objectives: Three operational types of abattoir, batch, slaughter and line abattoirs with their effluents (wastewater) were investigated for bacteriological quality in Lagos and Ogun states of Nigeria. The present study is a surveillance work to assess the housekeeping practices and the environmental impact of the three major abattoir types in Nigeria.

Methodology and Results: Spread plate and multiple-tube fermentation techniques were used in the analyses. Total bacterial counts (TBC) on workers' hands, butchering knives, slaughtering tables and floors ranged between $1.00 \times 10^{3}$ and $4.67 \times 10^{3} \mathrm{cfu} / \mathrm{ml}$ while total coliform count (TCC) of the effluents ranged between $1.5 \mathrm{x}$ $10^{6}$ and $1.0 \times 10^{2} \mathrm{MPN} / 100 \mathrm{ml}$ of Faecal coliform (FC). The highest numbers of isolated organisms (\% occurrence) were $42.0 \%, 21.9 \%, 21.9 \%$ and $14.3 \%$ for the Karra batch abattoir, RCCG Canaan land batch abattoir, Odo-eran slaughter slab and Ikenne line abattoir respectively. The following organisms were identified from the pure isolates contained in the samples from the various sources from the selected abattoir sites, namely, Citrobacter diversus, Erwinia chrysanthemi, Klebsiella oxytoca, Klebsiella pneumoniae, Serratia fonticola, Enterobacter aerogenes, Enterobacter intermedius, Escherichia coli.

Conclusions and application of findings: The line slaughter facilities conform to the WHO guidelines on setting up of an abattoir. However, slaughter slabs often violate the rules of public health, inspection and marketing regulations while in batch abattoir facilities no rules or guidelines are followed. These differences in modes of operation are reflected in the present microbiological analyses. However, the TCC of effluents for all the abattoir types examined exceeded recommended limit for discharge into surface water in Nigeria. Adoption of best practices such as updating most (if not all) abattoirs in Nigeria to line type and better enforcement of available regulations regarding limits on effluents from industrial facilities is recommended to reduce the negative health and environmental impact of abattoirs in Nigeria.
\end{abstract}

Key Words: abattoirs, coliform, effluents, wastewater

\section{INTRODUCTION}

Abattoirs are approved and registered facilities where animals are slaughtered and dressed for human consumption (Tompkin, 1994). The purpose of an abattoir is to produce hygienically prepared 
meat by the humane handling of the animal using hygienic techniques for slaughtering and dressing (FAO, 1992). However, meat contamination in abattoirs and meat stalls often result from contaminated water, unhygienic practices like poor handling, use of contaminated tables to display meat meant for sale and the use of contaminated knives in cutting operations (Fasanmi et al., 2010). Abattoirs are a major pollutant of the country side and cities, when the slaughter wastes are not properly managed, and especially, discharged into waterways, as such practices can introduce enteric pathogens and excess nutrients into surface water (Alonge, 1991). Slaughtering animals on a large scale is fraught with critical environmental and public health issues. The absence of potable water supplies coupled with the poor status of public infrastructures and unhygienic conditions of these abattoirs raise serious public health concern, as hygiene problems are not only limited to slaughtering but are also associated with incorrect processing of the animals (Akinro, 2009). Food and water-borne pathogens are the leading cause of illness and death in developing countries costing billions of dollars in medical care and social costs (Ayoade et al., 2013; Fratamico, 2005). Contaminated raw meat is one of the main sources of food-borne illnesses. The risk of the transmission of zoonotic infections is also associated with contaminated meat (Bhandare et al., 2007; Podpecan et al., 2007). Contamination of water bodies from abattoir waste constitutes significant environmental and public health hazards (Osibanjo and Adie, 2007; Nafarnda et al., 2006; Coker et al., 2001; World Bank, 1998). Bacteria from abattoir waste discharged into water columns can subsequently be absorbed to sediments, and when the bottom stream is disturbed, the sediment releases the bacteria back into the water columns presenting long-term health hazards (Sherer et al., 1992). In Nigeria, numerous abattoirs dispose their effluents directly into the streams and waterways without any type of treatment and the butchered meat is washed by the same water (Adelegan, 2002). Pathogens present in animal carcasses or shed in animal wastes may include rotaviruses, hepatitis E virus, Salmonella spp., E. coli 0157:H7, Yersinia enterocolitica, Campylobacter spp.,
Cryptosporidium parvum, Giardia lamblia and many members of the bacterial family Enterobacteriaceae (Sobsey et al., 2002). Members of the family Enterobacteriaceae are usually regarded as indicator organisms. These bacteria are used to provide evidence of poor hygiene, inadequate processing or post-process contamination of foods. Their absence in food provides a degree of assurance that the hygiene and food manufacturing process has been carried out appropriately, whereas their presence usually indicates that a potential problem or failure in the process has occurred. The Enterobacteriaceae and coliform bacteria within this family represent two of the most common groups of indicator organism used by the food industry. The genera normally regarded as coliforms include Enterobacter, Klebsiella, Citrobacter and Escherichia, particularly E. coli. However, others may include Hafnia alvei and strains belonging to genera such as Buttiauxella, Leclercia, Pantoea, Serratia, Yersinia etc. (Wallace et al., 2011). Regardless of construction style, components of an abattoir and other services should include the following; Lairage, slaughter hall, gut and tripe room, detained meat room, offal room, condemned meat room, hide and skin room. Others include cutting room, refrigeration room, supply of hot and cold water under pressure, veterinary inspection room, disinfection facilities, personnel welfare room, veterinary office and facilities for condemned meat offal or carcass disposal; incinerator, chemical treatment and disposal (Lawan et al., 2013). In most developing countries such as Nigeria, there are three main types of abattoirs, namely, the line slaughter, the slaughter slab and the batch systems. The line slaughter system is the most orderly and well-fitted in terms of customary abattoir configuration, furnishing, administration and conformation to the WHO guidelines on setting up of an abattoir (Eriksen, 1978). On the other hand, slaughter slabs that are the most commonly found in Nigeria are established and operated by municipal and local authorities. These operate in well-built areas and conform to a good extent with the WHO guidelines for abattoirs. However, the rules of public health, inspection and marketing regulations are often violated due to poverty, corruption and inadequate numbers of licensed butchers, traders 
and regulatory staff (Adeyemo, 2002). The worst managed abattoirs in Nigeria are the Batch type of slaughter system where animals are killed and processed sometimes on bare floor or on corrugated roofing sheets placed on the floor. These are usually located in abandoned buildings or under the shade of trees and open exposed grounds that a butcher might find suitable for the business. The present surveillance work is aimed at examining the

\section{MATERIALS AND METHODS}

Collection of Samples: Slaughtering floors, slaughtering tables, butchering knives, worker's hands and effluent water were aseptically collected from selected Line (Master meat, Ikenne, Ogun State), Slaughter slab (OkoOba, Lagos state) and Batch slaughter slabs (Kara, Lagos State and Odo-era, Canaan Land, Redemption Camp, Ogun State) using sterile swabs on all except water effluent. The sterile swabs were first dipped in normal saline before swabs were taken, water effluents were obtained in sterile containers. Samples were collected over a period of 3 months at random from each abattoir and labelled. Samples were collected in duplicates and coded. For the effluents (waste water), Multiple tube technique was used to obtain the MPN/ $100 \mathrm{ml}$ value as described by (Bachoon and Dustman, 2008). For this study, approval was obtained from the managers of the abattoirs and verbal consent was sought from the workers before swabs were taken. Questions were also asked from the abattoir managers the slaughtering process and general hygiene practices in the facilities. All samples were transported immediately to the laboratory for analyses. Emphasis was placed on members of the family Enterobacterioacae when screening for contaminants since most pathogenic contaminants come from this group. Moreover, members of this group are used as indicators of microbial contamination. This was done by plating the initial inoculates on Eosin Methylene Blue (EMB) agar. EMB contains dyes that are toxic for Gram-positive bacteria and bile salt, which is toxic for Gram-negative bacteria other than coliforms. EMB is the selective and differential medium for coliforms (Bachoon and Dustman, 2008).

Preparation of media and total viable count: All the media used in this study were prepared and sterilized according to manufacturer's instructions. The media used include Peptone water, eosin methylene blue agar, microbiological safety of meat processing and the public health problems associated with wastewater disposal in selected abattoirs in Lagos and Ogun States of Nigeria. Located in the South west geopolitical zone of Nigeria, these two states are arguably the most economically important states of the country of Nigeria, containing Lagos city, the nation's largest urban area (Filani, 2012).

Simons' citrate agar, nutrient agar. Urease agar base, MRVP (Methyl Red Voges-Proskauer) and Triple sugar iron agar; all obtained from Oxoid, UK. Inoculation was carried out aseptically with serial dilutions $\left(10^{-2}\right.$ to $\left.10^{-6}\right)$ of samples by spread plate technique using a glass spreader (hockey stick) and incubated at $30^{\circ} \mathrm{C}$ for $72 \mathrm{~h}$ (Adesemoye and Adedire, 2005). The numbers of organisms on the plates with distinct growth were counted after incubation.

Microbiological analyses: One (1) $\mathrm{ml}$ of wastewater was diluted in $9 \mathrm{ml}$ of sterile distilled water, followed by serial dilution. In the case of sterile swabs, the sterile swabs were first dipped in normal saline before swabs were taken, then shaken into $1 \mathrm{ml}$ of sterile distilled water. Sterile media were poured into plates after cooling to $45^{\circ} \mathrm{C}$ and allowed to further cool and solidify at room temperature. The serial diluents were aseptically inoculated into the plates and glass spreader was used to spread the inoculum. Sub-culturing was done until distinct colonies (pure cultures) were obtained. Pure cultures were isolated followed by biochemical tests to identify the isolates. Biochemical tests done using standard methods include; Gram stain, motility, urease activity, carbohydrate utilization, starch hydrolysis, gelatine hydrolysis, oxidase, catalase, indole production, citrate utilization, nitrate reduction and hydrogen sulphide production (Holt et al., 1994; Cappuccino and Sherma, 1998). The isolates were identified by comparing their characteristics with those of known taxa using the schemes of Bergey's Manual of Determinative Microbiology (Whitman et al., 2012).

Statistical analysis: All data were subjected to analysis of variance (ANOVA) while Duncan multiple range test was used to compare means found to be statistically significant $(p<0.05)$ according to the standard procedure described by (Steel and Torrie, 1980). 


\section{Ayoade and Olayioye J.Appl. Biosci. 2016 Microbiological assessment of housekeeping practices and environmental impact of selected abattoirs in Lagos and Ogun states of Nigeria}

\section{RESULTS}

Plates 1 and 2 show the stark contrast in physical appearance and operational ambience observable at the

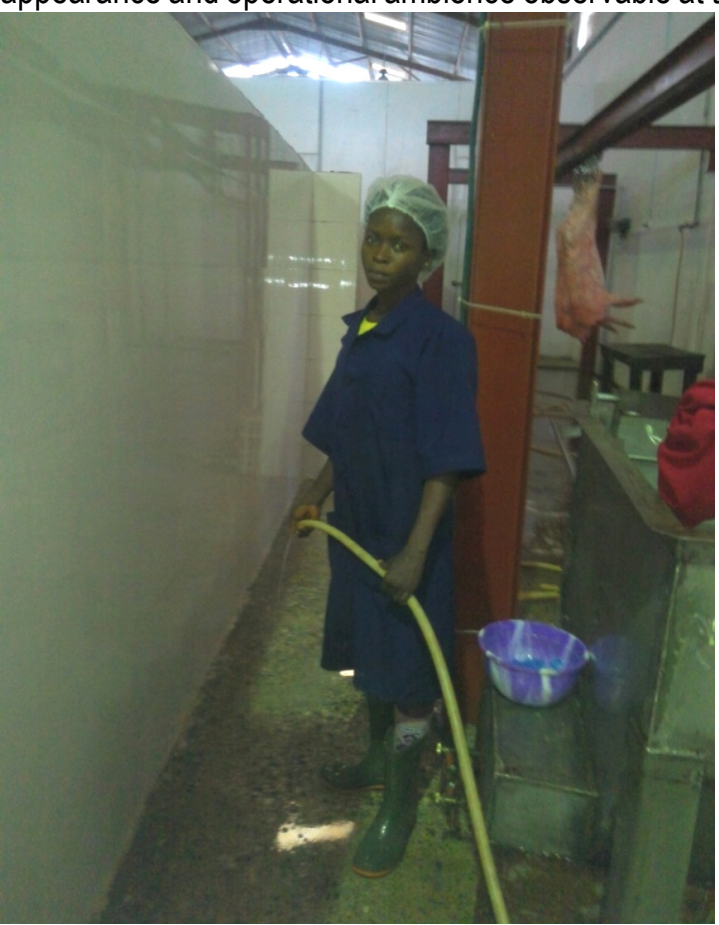

Line (Master Foods, Ikenne; Plate 1) and Batch type abattoirs (Kara; Plate 2).

Plate 1: The operation at the Master Foods Line abattoir (Ikenne) is orderly and the operatives are well-fitted with protective gear. In addition, there is a steady supply of hot and cold water under pressure. A processed animal is in the background, ready for refrigeration.

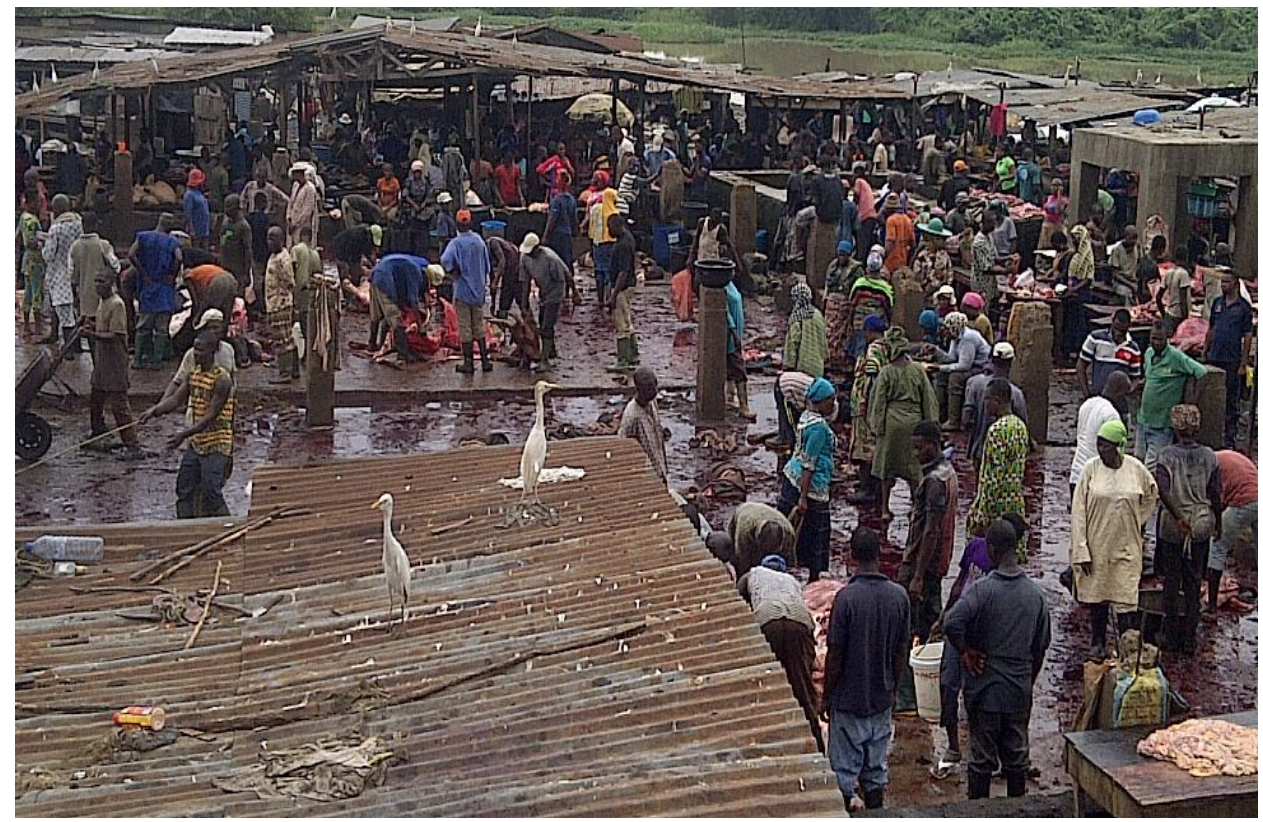

Plate 2: Picture of Kara abattoir showing evidence of animals killed and processed on the bare floor or on wooden planks/corrugated roofing sheets placed on the floor. 
As shown in Table 1, out of a total of 119 pure isolates obtained in the entire study from the workers' hands, butchering knives, slaughtering tables and floors at the different abattoir locations, the highest number of isolated organisms (\% occurrence) were obtained from Kara batch abattoir (42.0\%), RCCG Canaan land batch abattoir (21.9\%), Odo-eran slaughter slab (21.9\%) and lkenne line abattoir being the lowest (14.2\%). When typical contamination sites, namely, workers' hands, butchering knives, slaughtering tables and floors were compared for degree of contamination for the selected abattoir types, results showed that the line abattoir consistently had the lowest contaminants followed by the Oko-Oba slaughter slab, RCCG Canaan land batch and Kara batch abattoir in increasing degree of contamination (Table 2).

Table 1: Percent occurrence of bacterial isolates found in the various Abattoir types

\begin{tabular}{l|c|c}
\hline Location & Abattoir Type & ${ }^{*}$ Total No of pure Isolates \\
\hline Kara & Batch & $50(42.0)^{* *}$ \\
\hline Canaan Land & Batch & $26(21.9)$ \\
\hline Oko-Oba & Slaughter slab & $26(21.9)$ \\
\hline Ikenne & Line & $17(14.2)$ \\
\hline Total & & $119(100)$ \\
\hline
\end{tabular}

*This number represents the total number of distinct isolates obtained from the workers' hands, butchering knives, slaughtering tables and slaughtering floors.

${ }^{* *}$ Percentage of the total number of isolates observed for all sample sites shown in parentheses.

Table 2: Total bacterial counts (TBC; cfu/ml) sampled from workers' hands, butchering knives, slaughtering tables and floors at selected abattoirs.

\begin{tabular}{|c|c|c|c|c|c|c|c|c|c|}
\hline \multirow[t]{2}{*}{$\begin{array}{l}\text { Sample } \\
\text { location }\end{array}$} & \multirow[t]{2}{*}{$\begin{array}{c}\text { Abattoir } \\
\text { type }\end{array}$} & \multicolumn{2}{|c|}{ Workers' hands } & \multicolumn{2}{|c|}{ Butchering knives } & \multicolumn{2}{|c|}{$\begin{array}{c}\text { Slaughtering } \\
\text { tables }\end{array}$} & \multicolumn{2}{|c|}{$\begin{array}{l}\text { Slaughtering } \\
\text { floors }\end{array}$} \\
\hline & & Total & $\begin{array}{l}\text { Mean } \pm \text { Std } \\
\text { Dev (cfu/ml) }\end{array}$ & Total & $\begin{array}{l}\text { Mean } \pm \text { Std } \\
\text { Dev(cfu/ml) }\end{array}$ & $\begin{array}{c}\text { Tot } \\
\text { al }\end{array}$ & $\begin{array}{l}\text { Mean } \pm \text { Std } \\
\text { Dev(cfu/ml) }\end{array}$ & $\begin{array}{c}\text { Tot } \\
\text { al }\end{array}$ & $\begin{array}{l}\text { Mean } \pm \text { Std } \\
\operatorname{Dev}(\mathrm{cfu} / \mathrm{ml})\end{array}$ \\
\hline Kara & Batch & 13 & $\begin{array}{c}4.33 \times 10^{3} \pm 0 \\
03 a\end{array}$ & 11 & $\begin{array}{c}3.67 \times 10^{3} \pm 0.02 \\
a\end{array}$ & 14 & $\begin{array}{c}4.67 \\
\times 10^{3} \pm 0.07 a\end{array}$ & 12 & $\begin{array}{c}4.00 \\
\times 10^{3} \pm 0.01 a\end{array}$ \\
\hline $\begin{array}{l}\text { Canaan } \\
\text { land }\end{array}$ & Batch & 10 & $\begin{array}{c}3.33 \times 10^{3} \pm 0 . \\
07 \mathrm{~b}\end{array}$ & 10 & $\begin{array}{c}3.33 \\
\times 10^{3} \pm 0.04 a b\end{array}$ & 3 & $\begin{array}{c}1.00 \\
\times 10^{3} \pm 0.38 d\end{array}$ & 3 & $\begin{array}{c}1.00 \\
\times 10^{3} \pm 0.04 d\end{array}$ \\
\hline Oko-Oba & $\begin{array}{l}\text { Slaughter } \\
\text { slab }\end{array}$ & 9 & $\begin{array}{c}3.00 \times 10^{3} \pm 0 . \\
04 \mathrm{~b}\end{array}$ & 6 & $\begin{array}{c}2.00 \\
\times 10^{3} \pm 0.11 \mathrm{c}\end{array}$ & 6 & $\begin{array}{c}2.00 \\
\times 10^{3} \pm 0.06 \mathrm{c}\end{array}$ & 5 & $\begin{array}{c}1.67 \\
\times 10^{3} \pm 0.11 d\end{array}$ \\
\hline Ikenne & Line & 4 & $\begin{array}{c}1.33 \times 10^{3} \pm 0 \\
16 \mathrm{~d}\end{array}$ & 4 & $\begin{array}{c}1.33 \\
\times 10^{3} \pm 0.12 d\end{array}$ & 6 & $\begin{array}{c}2.00 \\
\times 10^{3} \pm 0.16 c\end{array}$ & 3 & $\begin{array}{c}1.00 \\
\times 10^{3} \pm 0.12 d\end{array}$ \\
\hline
\end{tabular}

Values are averages obtained when samples were taken in duplicates. Mean and standard deviation were analyzed by ANOVA and Duncan's multiple range test. Data with similar alphabets are not significantly different at $p \leq 0.05$.

As shown on Table 3, the following organisms were identified from the pure isolates contained in the samples from the various sources from the selected abattoir sites, namely, Citrobacter diversus, Erwinia chrysanthemi, Klebsiella oxytoca, Klebsiella pneumoniae, Serratia fonticola, Enterobacter aerogenes, Enterobacter intermedius, Escherichia coli. A location-by-location analysis of the type of organisms found in the samples is presented in Table 4. From Kara (batch type) abattoir, Erwinia chrysathemi (10 isolates), Klebsiella oxytoca (12 isolates), Klebsiella pneumonia (8 isolates), Serratia fonticola (15 isolates), Entrobacter aerogenes (5 isolates) were identified from samples collected. From Canaanland (batch type) abattoir, Citrobacter diversus (3 isolates), Erwinia chrysathemi (2 isolates), Klebsiella oxytoca (5 isolates), Escherichia coli (16 isolates) were identified from samples collected. From Oko-oba Slaughter slab abattoir, Citrobacter diversus (2 isolates), Erwinia chrysathemi (3 isolates), Klebsiella oxytoca (5 isolates), Enterobacter intermedius (6 isolates), Escherichia coli (10 isolates) were identified from samples collected. From Ikenne Line type abattoir, Erwinia chrysanthemi (5 isolates), Klebsiella oxytoca (12 isolates) were identified from samples collected. The most occurring organism found in all the abattoir types sampled was $K$. oxytoca $(28.6 \%)$ followed by $E$. coli $(21.9 \%)$, E. chrysanthemi (16.8\%), Serratia fonticola $(12.6 \%)$, K. pneumonia (6.7\%), E. intermedius (5.1\%) and 


\section{Ayoade and Olayioye J.Appl. Biosci. 2016 Microbiological assessment of housekeeping practices and}

environmental impact of selected abattoirs in Lagos and Ogun states of Nigeria

C diversus (4.2\%). It is remarkable that the line abattoir type displayed the least variety of contaminant organisms among the 3 various types of abattoirs sampled (Table 4). The results of the evaluation of effluents from the abattoirs show the degree of contamination of the effluents from worst to the least contaminated as follows:
Oko-Oba (Slaughter slab abattoir) > RCCG Canaan land (Batch abattoir) > Ikenne (Line abattoir) > Kara (batch abattoir); effluents from the batch abattoirs (Kara and RCCG Canaan land) displaying some of the lowest MPN/ $100 \mathrm{ml}$ of coliform bacteria (Table 5).

Table 3: Identification of isolates using cultural characteristics, cell morphology, gram staining and biochemical techniques.

\begin{tabular}{l|l|l|l|l|l|l|l|l|l|l}
\hline $\begin{array}{l}\text { Gram } \\
\text { staining }\end{array}$ & $\begin{array}{l}\text { Cell } \\
\text { shape }\end{array}$ & Lactose & Citrate & Urease & Indole & MR & VP & Lysine & $\mathbf{H}_{2} \mathrm{~S}$ & $\begin{array}{l}\text { Probable } \\
\text { organism }\end{array}$ \\
\hline$-(100)$ & $\mathrm{C}(100)$ & $+(\mathrm{G}, 100)$ & $+(100)$ & $+(20)$ & $+(100)$ & $+(100)$ & $-(100)$ & $+(100)$ & $-(100)$ & $\begin{array}{l}\text { Citrobacter } \\
\text { (diversus }) \\
\text { koseri }\end{array}$ \\
\hline$-(100)$ & $\mathrm{C}(100)$ & $+(100)$ & $+(100)$ & $+(20)$ & $+(100)$ & $+(100)$ & $+(100)$ & $+(100)$ & $-(100)$ & $\begin{array}{l}\text { Erwinia } \\
\text { chrysanthemi }\end{array}$ \\
\hline$-(100)$ & $\mathrm{C}(100)$ & $+(100)$ & $+(100)$ & $+(100)$ & $-(100)$ & $+(100)$ & $+(100)$ & $+(100)$ & $-(100)$ & $\begin{array}{l}\text { Klebsiella } \\
\text { oxytoca }\end{array}$ \\
\hline$-(100)$ & $\mathrm{C}(100)$ & $+(\mathrm{G}, 100)$ & $+(100)$ & $+(100)$ & $-(100)$ & $+(100)$ & $-(100)$ & $+(100)$ & $-(100)$ & $\begin{array}{l}\text { Klebsiella } \\
\text { pneumonia }\end{array}$ \\
\hline$-(100)$ & $\mathrm{C}(100)$ & $+(\mathrm{G}, 100)$ & $+(100)$ & $+(13.3)$ & $-(100)$ & $+(100)$ & $-(100)$ & $+(100)$ & $-(100)$ & $\begin{array}{l}\text { Serratia } \\
\text { fonticola }\end{array}$ \\
\hline$-(100)$ & $\mathrm{B}(100)$ & $+(\mathrm{G}, 100)$ & $+(100)$ & $+(80)$ & $-(100)$ & $+(100)$ & $+(100)$ & $+(100)$ & $-(100)$ & $\begin{array}{l}\text { Enterobacter } \\
\text { aerogenes }\end{array}$ \\
\hline$-(100)$ & $\mathrm{C}(100)$ & $+(100)$ & $+(100)$ & $+(83.3)$ & $-(100)$ & $+(100)$ & $-(100)$ & $+(100)$ & $-(100)$ & $\begin{array}{l}\text { Enterobacter } \\
\text { intermedius }\end{array}$ \\
\hline$-(100)$ & $\mathrm{C}(100)$ & $+(\mathrm{G}, 100)$ & $-(100)$ & $+(11.5)$ & $+(100)$ & $+(100)$ & $+(100)$ & $+(100)$ & $-(100)$ & $\begin{array}{l}\text { Escherichia } \\
\text { coli }\end{array}$ \\
\hline
\end{tabular}

$\mathrm{C}=$ Cocci; $\mathrm{B}=$ Bacillus; $\mathrm{G}=$ Gas producer; + = positive; - = negative

${ }^{*}$ The percentage of isolates of the respective organisms that tested positive or negative for the various biochemical tests are indicated in parentheses.

Table 4: Distribution of the probable organisms at the selected abattoirs

\begin{tabular}{l|c|c|c|c|c|c}
\hline Suspected bacteria & $\begin{array}{c}\text { Kara } \\
\text { (Batch) }\end{array}$ & $\begin{array}{c}\text { Canaan land } \\
\text { (Batch) }\end{array}$ & $\begin{array}{c}\text { Oko-Oba } \\
\text { (Slaughter slab) }\end{array}$ & $\begin{array}{c}\text { Ikenne } \\
\text { (Line) }\end{array}$ & Total & Percent \\
\hline Citrobacter diversus & - & $+(3)$ & $+(2)$ & - & 5 & 4.2 \\
\hline $\begin{array}{l}\text { Erwinia } \\
\text { chrysanthemi }\end{array}$ & $+(10)^{*}$ & $+(2)$ & $+(3)$ & $+(5)$ & 20 & 16.8 \\
\hline Klebsiella oxytoca & $+(12)$ & $+(5)$ & $+(5)$ & $+(12)$ & 34 & 28.6 \\
\hline $\begin{array}{l}\text { Klebsiella } \\
\text { pneumonia }\end{array}$ & $+(8)$ & - & - & - & 8 & 6.7 \\
\hline Serratia fonticola & $+(15)$ & - & - & - & 15 & 12.6 \\
\hline $\begin{array}{l}\text { Enterobacter } \\
\text { aerogenes }\end{array}$ & $+(5)$ & - & - & - & 5 & 4.2 \\
\hline $\begin{array}{l}\text { Enterobacter } \\
\text { intermedius }\end{array}$ & - & - & $+(6)$ & - & 6 & 5.0 \\
\hline Escherichia coli & - & $+(16)$ & $+(10)$ & - & 26 & 21.9 \\
\hline Total (\%) & 50 & 26 & 26 & 17 & 119 & 100 \\
\hline
\end{tabular}

${ }^{*}$ The total number of isolates of the respective organisms and the locations where they were isolated from are indicated in parentheses. 
Table 5: Total coliform count of wastewater from the selected abattoirs

\begin{tabular}{l|l|l}
\hline Sample Location & Abattoir type & $\begin{array}{l}\text { Total Coliform Count } \\
\text { MPN/100ml }\end{array}$ \\
\hline Kara & Batch & $1.0 \times 10^{2}$ \\
RCCG Canaan land & Batch & $1.4 \times 10^{6}$ \\
Oko-Oba & Slaughter slab & $1.5 \times 10^{6}$ \\
Ikenne & Line & $1.0 \quad \times 10^{5}$ \\
\hline
\end{tabular}

* Effluent limit for discharge into surface water in Nigeria is $4.0 \times 10^{2} \mathrm{MPN} / 100 \mathrm{ml}$

${ }^{* *}$ Effluent limit for discharge for land water in Nigeria is $5.0 \times 10^{2} \mathrm{MPN} / 100 \mathrm{ml}$

${ }^{* * *}$ Effluent limits were obtained from (Nafarnda et al., 2012)

\section{DISCUSSION}

When abattoir facilities are not in conformity with standard conventional requirements or when such facilities are available but non-functional, standard operating procedure and good hygiene practices are violated in the abattoirs and this situation may pose danger to the public health (Stevenson, 2001). Results from the present research confirm this assertion as illustrated in Plates 1,2 and Table 1. When basic amenities such as supply of hot and cold water under pressure, veterinary inspection room, disinfection and meat inspection facilities are unavailable as it was in the case of the batch system abattoirs examined in this study, a corresponding increase in the number of microbial contaminants is observed. The lowest number of contaminant organisms was isolated from the Line abattoir, which conformed to the Effluent limit for discharge into surface water in Nigeria which is $4.0 \times 10^{2} \mathrm{MPN} / 100 \mathrm{ml}$ and a limit of $5.0 \mathrm{x}$ $10^{2} \mathrm{MPN} / 100 \mathrm{ml}$ for discharge into land water in Nigeria (FEPA, 1991). The converse was the case for the batch abattoirs that were rife with blatant violations of standard operating procedure for setting up and running abattoirs; these presented the highest number of contaminant organisms found in the entire study. The range of total coliform count recorded for wastewater effluent discharged from the abattoir sites evaluated in the present study was $1.0 \times 10^{2}$ to $1.5 \times 10^{6}$ (Table 5). This correlates well with an earlier survey done at Oko-Oba, Agege abattoir, Lagos, Nigeria, one of the abattoirs evaluated in the present study. In that previous study, the mean total bacterial count of the replicates taken from Oko-Oba, Agege abattoir was reported to be $3.32 \times 10^{7}$ cfu/ml (Adesemoye et al., 2006), in the present study, a total coliform count of $1.5 \times 10^{6}$ was found. Moreover, the values reported in the present study falls within and in some cases slightly lower than those reported earlier by Nafarnda et al. (2012) showing a range of $4.8 \times 10^{6}$ to 5.8 $\times 10^{5} / 100 \mathrm{~mL}$ of total coliform (TC), $8.2 \times 10^{4}$ to $3.2 \times$ $104 / 100 \mathrm{~mL}$ of Faecal coliform (FC) in Abuja, North Central Nigeria. Furthermore, results from the present study (Table 5) show that all of the waste water effluents from the examined abattoirs except the Kara batch abattoir exceeded the set daily limits for discharge of coliforms into surface and land water. Kara abattoir is peculiar due its close proximity to the nearby Ogun River into which most of the abattoir workers dump the untreated animal wastes directly, thereby making an accurate assessment of the waste water effluent a nearimpossible task. This observation has dire implications for the receiving water bodies particularly downstream.

Bacteria isolated from both wastewater and operational areas of abattoirs evaluated in the present study identified the following members of the family Enterobacteriacae as the bacterial contaminants: Citrobacter diversus, Erwinia chrysanthemi, Klebsiella oxytoca, Klebsiella pneumoniae, Serratia fonticola, Enterobacter aerogenes, Enterobacter intermedius, Escherichia coli. These results compare favourably well with earlier reports from both waste water and soil samples from ljebu Igbo abattoir, in Ogun State of Nigeria. ljebu-lgbo is located in Ogun State, one of the locations sampled in the present study. The contaminant bacteria reported in that earlier study from ljebu Igbo include Escherichia coli, Klebsiella pneumonia, Staphylococcus aureus, Proteus mirabilis, Serratia sp., Pseudomonas putida, Enterobacter aerogenes (Neboh et al., 2013). Moreover, Ogbonna (2014) earlier reported the occurrence of the following contaminants from a similar study carried out in Port Harcourt, South Eastern Nigeria, namely, Klebsiella, Enterobacter, Escherichia, Salmonella, Shigella, Citrobacter, Serratia and Proteus. On the other hand, Nafarnda et al. (2012) reported the presence of only $E$. coli and faecal Streptococcus in another study from Port Harcourt, Nigeria. It should be noted however that the Nafarnda et al., (2012) study was focused only in isolating $E$. coli and faecal streptococcus as indicator organisms. The present study not only screened for the entire members of the Family Enterobacteriacae as indicator organisms as evidence of faecal contamination but went further to identify the 
particular contaminant organisms. The organisms such as those isolated from the abattoir sites and waste water samples reported in this study are a normal part of the gut flora found in the intestines, tripes and offals of livestock animals, while others are found in water or soil, or are parasites on a variety of different animals and plants as is commonly found at abattoir sites. These organisms produce endotoxins that, when released into the bloodstream following cell lysis, cause systemic inflammatory and vasodilatory response. The most severe form of this is known as endotoxic shock, which can be rapidly fatal. Moreover, they are often the causes of outbreaks of gastroenteritis, urinary tract infections and neonatal meningitis (Wallace et al., 2011). The absence of other famous contaminant species usually found globally in abattoirs such as Salmonella spp., Yersinia enterocolitica from the present species mix is not surprising since these are more often associated with poultry and swine abattoirs. The abattoirs evaluated in the present study process cattle for beef and associated products. Moreover, Salmonella may not be so frequently registered in abattoir waste water due to the great amount of competing bacteria that cut short the multiplication of Salmonella. The bacterium fails to survive during long periods under certain circumstances. Furthermore, the low sampling (a single sample) with low periodicity (once

\section{CONCLUSION AND RECOMMENDATIONS}

The present work observed that the facilities examined are badly managed, evidenced by microbial contamination. In addition, that abattoir wastewater effluent from these abattoirs often exceed set limits by the Nigerian regulatory organization- the Federal Environmental Protection Agency (FEPA, 1991) which is established for enforcing available laws to protect the public from potential disease outbreaks emanating from a month; sometimes once a year) may not be able to pick organisms that are transient. Simple samplings may not always be used for specific problems (Barros et al., 2007). The promotion of personal hygiene such as simple hand washing and proper cleaning of equipment used in food handling is a major challenge for infection control experts. A wide range of bacterial infections are associated with poor personal hygiene, ranging from flu to respiratory infections. For example, diverse bacterial infections are transmitted from the contact of the hand with animals, surfaces or humans contaminated with the causative bacteria; nosocomial infections, faecal-oral route infections, droplets on surfaces and resident/ transient organisms moving from normal flora to respiratory tracts (Larson, 1999). The results from the present work underscore the poor hygiene practices at the abattoir sites. Simple personal hygiene practices such as hand-washing and proper cleaning of cutting knives, cleaning of tables etc goes a long way in prevention of the spread of contaminants with the attendant public health implications. The line abattoir presented the lowest values for bacterial count at the various locations sampled for indication of poor hygiene practices (Table 2). This was followed by the slaughter slab; the batch abattoir types presented the worst indices for personal hygiene practices.

these facilities. Moreover, it was observed that the rules of public health, inspection and marketing regulations are often violated due to poverty, corruption and inadequate numbers of licensed butchers, traders and regulatory staff. Adoption of best practices in Nigerian abattoirs and better enforcement of available regulations is recommended to reduce the negative health and environmental impact of abattoirs in Nigeria.

\section{CONFLICT OF INTEREST STATEMENT}

None declared.

ACKNOWLEDGMENTS This research was funded personally by the authors. The valuable technical assistance of Messrs Scott Fayemi, Mr. Nick Oyejide, Gboyega Daramola and Ms. Ayo Olaoye is gratefully acknowledged.

\section{REFERENCES}

Adelegan J.A. 2002. "Enviromental policy and slaughter waste in Nigeria", proceedings of the $28^{\text {th }}$ EWDC Conference, Calcutta, India.

Adesemoye, A. O., Opere B. O., Makinde, S. C. O., 2006. Microbial content of abattoir wastewater and its contaminated soil in Lagos, Nigeria,
African Journal of Biotechnology Vol. 5 (20), pp. 1963-1968.

Adesemoye, A.O., Adedire, C.O. 2005. "Use of cereals as basal medium for the formulation of alternative culture media for fungi", World $\mathrm{J}$. Microbiol. Biotechnol., 21: 329-336. 
Adeyemo, O.K. 2002. "Unhygienic Operations Of a City Abattoir In South Western Nigeria: environmental implications". AJEAM/RAGEE, 4(1): 23-27.

Akinro, A.O., Ologunagba, I.B., Yahaya, O. 2009. "Environmental implication of unhygienic operation of a city abattoir in Akure, Western Nigeria", Journal of Engineering and Applied Sciences, 4(9): 61-63.

Alonge, D. O., 1991. "Textbook of Meat Hygiene in the Tropics", Farmcoe Press, Ibadan, 58pp.

Ayoade, F., Fayemi, S.O., Daramola, G.G., Osho, A., Oyejide, N.E., Adenodi, S.A., Anazodo, K.O. 2013. "Effectiveness of storage as a point-of-use means of improving the bacteriological quality of drinking water", Int. J. Biol. Chem. Sci., 7(1): 96106.

Bachoon, D S., Dustman, W. A. 2008. Microbiology Laboratory Manual. Ed. Michael Stranz. Mason, $\mathrm{OH}$ : Cengage Learning, Exercise 8, "Selective and Differential Media for Isolation" Print.

Barros, L. S., Amaral, S., Lorenzon, L. A., Junior, C. S., Neto, J. G. 2007. Potential microbiological contamination of effluents in poultry and swine abattoirs. Epidemiology and infection, 135(03), 505-518.

Bhandare, S.G., Sherikarv, A.T., Paturkar, A.M., Waskar, V.S., Zende, R.J. 2007. "A comparison of microbial contamination on sheep/goat carcasses in a modern Indian abattoir and traditional meat shops" Food Control, 18: 854868.

Cappuccino, J.G., Sherma, N. 1998. "Standard qualitative analysis of water", In: Microbiology: A laboratory manual, 5 th ed. Benjamin/Cummings Publishing Co, England, pp 297-303.

Coker, A. O., Olugasa, B. O., Adeyemi, A. O. 2001. "Abattoir and wastewater quality in South Western Nigeria," in Proceedings of the 27thWater, Engineering and Development Centre Conference, Lusaka, Zambia.

Eriksen, P. J. 1999. "Slaughter house and slaughter lab design and construction", FAO Animal production \& wealth paper NV.9 FAO Rome Larson, E Skin Hygiene and Infection Prevention: More of the Same or Different Approaches?, Clin Infect Dis., 29 (5):1287-1294 .doi: $10.1086 / 313468$

Fasanmi, G. O., Olukole, S. G., Kehinde, O. O. 2010. "Microbial studies of table scrapings from meat stalls in Ibadan Metropolis, Nigeria: Implications on meat hygiene", African Journal of Biotechnology, Vol. 9 (21): 3158-3162.

Federal Environmental Protection Agency (FEPA), 1991. Guidelines and Standards for Industrial Effluents, Gaseous Emission and Hazardous Waste Management in Nigeria, Part II, Chapter 1, Sub Section 1.3., Abuja, FCT, Nigeria.

Filani, M.O. 2012. "The changing faces of Lagos: From Vision to reform and transformation" accessed on 12-08-2015 from http://www.citiesalliance.org /sites/citiesalliance.org/files/Lagos-reformreport-lowres.pdf

Food and Agricultural Organization (FAO), 1992. "Construction and operation of medium-sized abattoirs in developing countries", In: 97th Animal Production and Health Paper, Pp 1-104.

Fratamico, P.M., Bhunia, A.K., Smith, J.L. 2005. "Foodborne Pathogens in Microbiology and Molecular Biology", Caister Academic Press, Wymondham, Norfolk, UK. 273 pp.

Holt, J. G., Krieg, N. R. Sneath, P. H. A., Staley, J. T., Williams, S. T. 1994. "Aerobic chemolithotrophic bacteria and associated organisms", Bergey's manual of determinative bacteriology, 9th ed. Williams \& Wilkins, Baltimore, USA, 427-455.

Larson, E. 1999. "Skin hygiene and infection prevention: more of the same or different approaches?", Clinical Infectious Diseases, 29(5), 1287-1294.

Lawan, M.K., Bello, M., Kwaga, J.K.P., Raji, M.A. 2013. "Evaluation of physical facilities and processing operations of major abattoirs in North-western states of Nigeria" Sokoto Journal of Veterinary Sciences, 11(1):56-61,2013. http://dx.doi.org/10.4314/sokjvs.v11i1.9

Nafarnda, W. D., Ajayi, I. E. Shawulu, J. C., Kawe, M. S., Omeiza, G. K., Sani, N. A. , Dantong, D. D. 2012. Bacteriological quality of abattoir effluents discharged into water bodies in Abuja, Nigeria. ISRN veterinary science,

Nafarnda, W. D., Yaji, A., Kubkomawa, H. I. 2006. "Impact of abattoir waste on aquatic life: a case study of Yola abattoir," Global Journal of Pure and Applied Sciences, 12: 31-33.

Neboh, H. A., Ilusanya, O. A., Ezekoye, C. C., Orji, F. A. 2013. Assessment of ljebu-lgbo Abattoir effluent and its impact on the ecology of the receiving soil and river. Journal of Science, Toxicology and Food Technology, 7(5), 2319-2402.

Ogbonna, D. N. 2014. Distribution of Microorganisms in Water, Soils and Sediment from Abattoir Wastes 
in Southern Nigeria. Int. J. Curr. Microbiol. App. Sci, 3(9), 1183-1200.

Osibanjo, O. and Adie, G. U. 2007. "Impact of effluent from Bodija abattoir on the physicochemical parameters of Oshunkaye stream in Ibadan City, Nigeria," African Journal of Biotechnology, 6, (15): 1806-1811.

Podpečan, B., Pengov, A., Vadnjal, S. 2007. "The source of contamination of ground meat for production of meat products with bacteria Staphylococcus aureus", Slov Vet Res, 44: 25-30.

Sherer, B. M., Miner, R. J., Moore, J. A., Buckhouse, J. C. 1992. "Indicator bacterial survival in stream sediments," Journal of Environmental Quality, 21 (4): 591-595.

Sobsey, M. D., Khatib, L. A., Hill, V. R., Alocilja, E., Pillai, S. 2002. "Pathogens in Animal Wastes and the Impacts of Waste Management Practices on their Survival, Transport, and Fate," White paper for The National Center for Manure \& Agricultural Waste Management.

Steel, R. G. D., Torrie, J. H. 1980. "Duncan's new multiple range test, Principles and procedures of statistics", 187-188.
Stevenson, P. 2001. "Animal welfare problems in UK slaughterhouses, Compassion in World farming".

Tompkin R. B., 1994. "HACCP in the meat and poultry industry", Food Control, 5(3), 153-161.

Wallace, T. C., Guarner, F., Madsen, K., Cabana, M. D., Gibson, G., Hentges, E., Sanders, M. E. 2011. "Human gut microbiota and its relationship to health and disease", Nutrition reviews, 69 (7), 392-403.

Whitman, W.B., Goodfellow, M., Kämpfer, P., Busse, H. J., Trujillo, M.E., Ludwig, W., Suzuki, K., Parte, George A., Garrity, M. ed., 2012. "The Actinobacteria. Bergey's Manual of Systematic Bacteriology" 4 (2nd ed.). New York: Springer. p. 1750. ISBN 978-0-387-95043-3. British Library no. GBA561951.

World Bank, 1998. "Poor Management of Processing Wastes. Environmental Assessment: Pressure State Response Indicators," Pollution Prevention and Abatement Handbook. 